\title{
Phototrophic oxidation of ferrous iron by a Rhodomicrobium vannielii strain
}

\author{
Silke Heising and Bernhard Schink
}

Author for correspondence: Bernhard Schink. Tel: +497531 882140. Fax: +497531882966. e-mail: Bernhard.Schink@uni-konstanz.de

Fakultăt für Biologie, Universitat Konstanz, Postfach 5560, D-78434 Konstanz, Germany

\begin{abstract}
Oxidation of ferrous iron was studied with the anaerobic phototrophic bacterial strain BS-1. Based on morphology, substrate utilization patterns, arrangement of intracytoplasmic membranes and the in vivo absorption spectrum, this strain was assigned to the known species Rhodomicrobium vannielii. Also, the type strain of this species oxidized ferrous iron in the light. Phototrophic growth of strain BS-1 with ferrous iron as electron donor was stimulated by the presence of acetate or succinate as cosubstrates. The ferric iron hydroxides produced precipitated on the cell surfaces as solid crusts which impeded further iron oxidation after two to three generations. The complexing agent nitrilotriacetate stimulated iron oxidation but the yield of cell mass did not increase stoichiometrically under these conditions. Other complexing agents inhibited cell growth. Ferric iron was not reduced in the dark, and manganese salts were neither oxidized nor reduced. It is concluded that ferrous iron oxidation by strain BS-1 is only a side activity of this bacterium that cannot support growth exclusively with this electron source over prolonged periods of time.
\end{abstract}

Keywords: iron metabolism, phototrophic bacteria, Rhodomicrobium vannielii, iron complexation, nitrilotriacetate (NTA)

\section{INTRODUCTION}

Iron is the fourth most important element in the Earth's crust, making up about $5 \%$ of the total crust mass (Ehrlich, 1990). In biological systems, the redox change between the $\mathrm{Fe}(\mathrm{II})$ and the $\mathrm{Fe}(\mathrm{III})$ state is of utmost importance in redox reactions, especially in haemcontaining proteins, iron-sulfur proteins, etc. (Neilands, 1974). The redox change between $\mathrm{Fe}$ (II) and $\mathrm{Fe}$ (III) also plays an important role in the mineralization of biomass in oxygen-limited environments such as sediments, water-logged soils or contaminated aquifers (Lovley, 1993). The redox potential of the $\mathrm{Fe}$ (II)/ $\mathrm{Fe}$ (III) transition depends strongly on the prevailing $\mathrm{pH}$ : at strongly acidic conditions, the transition occurs at the standard redox potential of $+0.77 \mathrm{~V}$, whereas at $\mathrm{pH} 7.0$, the transition redox potential is between +0.1 and $+0.2 \mathrm{~V}$ (Stumm \& Morgan, 1981; Widdel et al., 1993). This comparatively low redox potential caused us to check whether anoxygenic phototrophic bacteria could oxidize ferrous to ferric iron compounds with concomitant reduction of $\mathrm{CO}_{2}$ to cell material. Enrichment cultures led to the isolation of several pure cultures of

Abbreviation: NTA, nitrilotriacetate. anoxygenic purple bacteria, including a Rhodomicrobium vannielii-like isolate (Widdel et al., 1993). Other strains of purple phototrophs able to oxidize ferrous iron are strain L7, a non-motile rod with gas vacuoles which is related to the genus Chromatium, and strain SW2, a non-motile rod related to the genus Rhodobacter. Both strains can use not only $\mathrm{FeCO}_{3}$ but also $\mathrm{FeS}$ as electron source, and can oxidize it completely to $\mathrm{Fe}$ (III) and sulfate (Ehrenreich \& Widdel, 1994).

In the present communication, a purple non-sulfur bacterium is described in detail which was isolated with ferrous iron as sole energy source in the light (Widdel $e t$ al., 1993). The strain was characterized as belonging to the species $R m$. vannielii, and the type strain of this species was also found to be able to oxidize ferrous iron.

\section{METHODS}

Sources of organisms. Strain BS-1 was enriched from the sediment of a ditch close to Tübingen-Bebenhausen, Germany. The following strains were obtained from the Deutsche Sammlung für Mikroorganismen und Zellkulturen, Braunschweig, Germany : Rhodobacter capsulatus DSM 155, Rhodobacter sphaeroides DSM 158 ${ }^{\mathrm{T}}$, Rhodobacter sulfidophilus (Rhodovulum sulfidophilum) DSM $1374^{\mathrm{T}}$, Rhodomicrobium vannielii DSM $162^{\mathrm{T}}$, Rhodopseudomonas acidophila DSM 
$137^{\mathrm{T}}$, Rhodopseudomonas palustris DSM $123^{\mathrm{T}}$, Rhodospirillum rubrum DSM $467^{\mathrm{T}}$ and Rubrivivax gelatinosus DSM $149^{\mathrm{T}}$. Rhodobacter sulfidophilus (Rhodovulum sulfidophilum) strain SiCys (Heising et al., 1996) was from our own culture collection.

Media and growth conditions. All strains were cultivated in a sulfide-free mineral medium designed for growth of nonsulfur purple bacteria (Pfennig \& Trüper, 1991) which was buffered with $30 \mathrm{mM}$ bicarbonate and contained $1 \mathrm{mM}$ sulfate as sulfur source. Vitamins were added from a stock solution (Pfennig, 1978); Rm. vannielii received an additional amount of riboflavin [ $\left.50 \mu \mathrm{g}(1 \mathrm{medium})^{-1}\right]$. The marine bacterium Rhodobacter sulfidophilus was cultivated in a similar medium with enhanced salt content $\left(7 \mathrm{~g} \mathrm{NaCl}\right.$ and $\left.1 \mathrm{~g} \mathrm{MgCl}_{2} \mathrm{I}^{-1}\right)$. Substrates were added from sterile neutralized stock solutions. Ferrous iron was added to a final concentration of $8 \mathrm{mM}$ from a $0.8 \mathrm{M} \mathrm{FeSO}_{4}$ solution that was prepared and filter-sterilized under $\mathrm{N}_{2}$ gas and kept under $\mathrm{N}_{2}$ at $4{ }^{\circ} \mathrm{C}$. Reaction of ferrous iron with bicarbonate led to the formation of a white precipitate of siderite $\left(\mathrm{FeCO}_{3}\right)$. The $\mathrm{pH}$ was adjusted to 6.8 throughout.

Chelators were added to the medium before addition of $\mathrm{FeSO}_{4}$ to avoid precipitation. Ferrous nitrilotriacetate (Fe-NTA) was supplied from a filter-sterilized stock solution. Iron-free controls were run with NTA that was preincubated with equivalent amounts of $\mathrm{NaCl}$ or $\mathrm{MgCl}_{2}$. Ferrous sulfide was prepared by precipitation of $0.2 \mathrm{M} \mathrm{Na} 2 \mathrm{~S}$ solution in $10 \mathrm{mM}$ $\mathrm{NaOH}$ with an equal volume of $0.2 \mathrm{M} \mathrm{FeSO}_{4}$ in $10 \mathrm{mM} \mathrm{HCl}$ under $\mathrm{N}_{2}$ atmosphere. The precipitate was washed twice with sulfide-free mineral medium (Ehrenreich \& Widdel, 1994). Ferric oxohydroxide (FeOOH) was prepared by slow neutralization of $0.4 \mathrm{M} \mathrm{FeCl}_{3}$ with $0.5 \mathrm{M} \mathrm{NaOH}$. The precipitate was washed three times with distilled water to make a final solution of approximately $0.4 \mathrm{M} \mathrm{FeOOH}$ (Lovley \& Phillips, 1986). $\mathrm{Fe}$ (III) citrate was prepared as a $0.2 \mathrm{M}$ stock solution from ammonium $\mathrm{Fe}$ (III) citrate (green) and ammonium $\mathrm{Fe}$ (III) citrate (brown). Excess citrate was bound by addition of $\mathrm{MgCl}_{2}$. Manganese(II) sulfate was tested as electron donor at $4 \mathrm{mM}$ final concentration. It precipitated with bicarbonate ions to form reddish-white $\mathrm{MnCO}_{3}$ (rhodochrosite). The stock solution was maintained under $\mathrm{N}_{2}$ atmosphere. $\mathrm{MnO}_{2}$ was prepared by reaction of $30 \mathrm{mM} \mathrm{MnCl}$ solution and $20 \mathrm{mM} \mathrm{KMnO}$ s solution. The precipitate was washed with distilled water until no chloride was detectable in an $\mathrm{AgNO}_{3}$ test solution (Lovley \& Phillips, 1988).

Bacteria were grown in $50 \mathrm{ml}$ screw-cap bottles filled to the top with liquid medium. Utilization of $\mathrm{H}_{2}$ was tested in rubber-sealed serum bottles with a $\mathrm{H}_{2} / \mathrm{CO}_{2}(80: 20)$ headspace. Utilization of substrates was checked in $22 \mathrm{ml}$ screwcap tubes. Cultures were incubated at $25^{\circ} \mathrm{C}$ at a distance of approximately $40 \mathrm{~cm}$ from a $40 \mathrm{~W}$ bulb (equivalent to $14 \mathrm{~W}$ $\mathrm{m}^{-2}$ ). Formation of orange-brown precipitates indicated ferrous iron oxidation. Enrichment cultures were purified in deep-agar dilution series (Pfennig \& Trüper, 1991). FeSO $\mathrm{S}_{4}$ was added as a sterile solution to the agar before the liquid medium was added, to allow homogeneous distribution of $\mathrm{FeCO}_{3}$ through the entire medium. Culture purity was checked at regular intervals by phase-contrast microscopy after growth in mineral medium or in complex media (AC-medium, Difco, diluted $1: 10$ ).

Microscopy and spectroscopy. For electron microscopy, cells were fixed with $3 \%$ glutardialdehyde and $1 \%$ osmium tetroxide, and embedded after Spurr (1969). Ultrathin sections were contrasted with uranyl acetate and lead citrate (Mayer $e t$ al., 1977) and viewed with a Philips EM 301 electron microscope.
In vivo absorption spectra were taken in cell suspensions supplied with $5 \mathrm{~g}$ sucrose per $5 \mathrm{ml}$ culture fluid to avoid excessive light refraction. Spectra were taken with a Shimadzu UV-300 spectrophotometer in end-on position. Cells grown with ferrous iron were washed twice with $10 \mathrm{mM}$ EDTA in

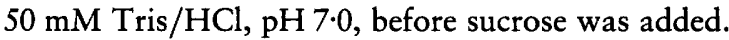

Analytical methods. For analysis of iron salts, $5 \mathrm{ml}$ precipitatefree culture fluid was removed from $50 \mathrm{ml}$ culture bottles and replaced with $5 \mathrm{ml} 37 \% \mathrm{HCl}$ to dissolve all iron precipitates. Ferrous iron was quantified by the ferrozine method (Stookey, 1970); total iron was quantified by the same method after reduction with hydroxylamine. The difference between ferrous iron and total iron was taken as ferric iron (Stookey, 1970). Sulfide was quantified colorimetrically after Cline (1969). Acetate was assayed by gas chromatography (Platen \& Schink, 1987).

Biochemical methods. Cells were harvested at $13000 \mathrm{~g}$ at $4{ }^{\circ} \mathrm{C}$ for $30 \mathrm{~min}$. The pellet was washed twice with $50 \mathrm{mM}$ MOPs

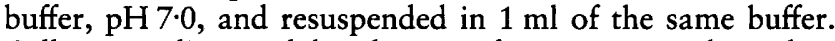
Cells were disrupted by three to four passages through a French Press cell (Aminco) at $136 \mathrm{MPa}$. SDS-PAGE followed standard methods (Laemmli, 1970). Samples were pretreated in $60 \mathrm{mM}$ Tris $/ \mathrm{HCl}, \mathrm{pH} 6.8$, in the presence of $5 \%(\mathrm{v} / \mathrm{v})$ mercaptoethanol plus $10 \%(\mathrm{v} / \mathrm{v})$ glycerol, $2 \%(\mathrm{w} / \mathrm{v}) \mathrm{SDS}$ and $0.025 \%(\mathrm{w} / \mathrm{v})$ bromophenol blue. Samples were boiled at $100{ }^{\circ} \mathrm{C}$ in a water bath for $5 \mathrm{~min}$. Separation occurred in a Mini-Protean II Dual Slab Cell (Bio-Rad) at a current of 15-20 mA. Gels were stained with Coomassie brilliant blue R250 and destained with $10 \%(\mathrm{v} / \mathrm{v})$ acetic acid. Cytochromes were stained specifically by the haem peroxidase assay (Thomas et al., 1976).

Chemicals. All chemicals were of analytical grade purity and purchased from Alfa Products, Karlsruhe, Boehringer Mannheim, Fluka, Neu-Ulm, Merck, Darmstadt, Riedel de Haen, Seelze and Serva. Gases at purity standard 5.0 were supplied by Sauerstoffwerke.

\section{RESULTS}

\section{Enrichment of iron-oxidizing bacteria}

Sediment samples from a ditch close to TübingenBebenhausen were used as inocula in mineral medium with $2 \mathrm{mM} \mathrm{FeSO}_{4}$ as electron source at $25^{\circ} \mathrm{C}$ in $\operatorname{dim}$ light $\left(14 \mathrm{~W} \mathrm{~m}^{-2}\right)$. After 1-2 weeks incubation, brownish precipitates formed on the bottle surfaces, and precipitated material collected at the bottom. Transfers were made into subcultures with some of the surfaceattached material and also with free culture liquid. In subcultures, mainly stalked bacteria developed which were associated with the bottle surfaces and with ferric iron precipitates. After three to four transfers, the cell material was diluted in deep-agar series for purification. Colonies developing in these cultures were deep brown and either round with entire margins or fluffy. Under microscopic examination, both types of colonies were dominated by stalked bacteria. Since isolation and resuspension of ferric-hydroxide-containing colonies proved to be difficult, strains were isolated in deep-agar dilution series with $4 \mathrm{mM}$ succinate as substrate. The developing colonies were deep red and contained the same type of stalked bacteria as observed in the enrichment cultures. Strain BS-1 was characterized in detail. 

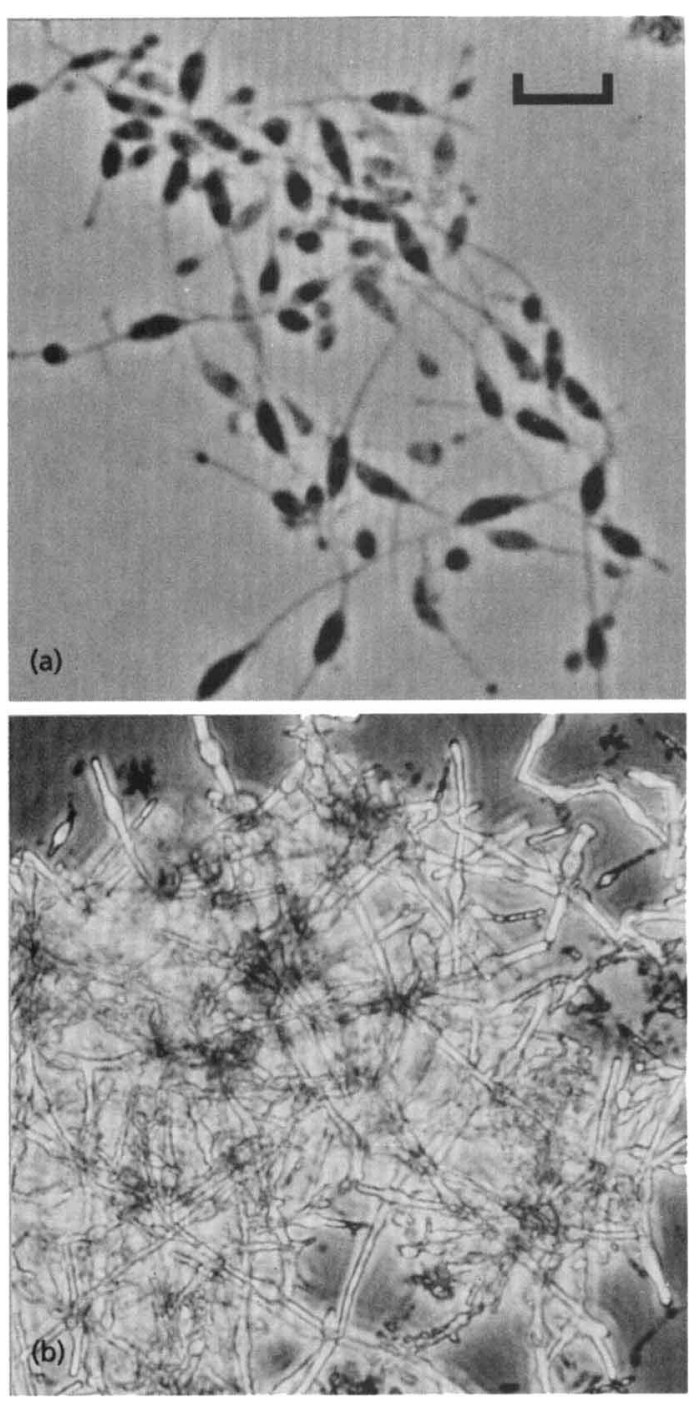

Fig. 1. Phase-contrast photomicrographs of strain BS-1 grown with succinate (a) or ferrous iron plus butyrate (b). Bar, $5 \mu \mathrm{m}$.
During exponential growth, cells of strain BS-1 were either motile rods or stalked cells, $0.7 \mu \mathrm{m}$ wide and $2 \mu \mathrm{m}$ long. After growth with succinate, cells formed thin stalks which aggregated in nets, reminiscent of the morphology of Rm. vannielii (Fig. 1a). In the stationary phase, polyhedral exospores developed. Cultures of strain BS-1 with $8 \mathrm{mM} \mathrm{FeSO}_{4}$ plus $1 \mathrm{mM}$ acetate or butyrate as substrate required 6-8 weeks for iron oxidation to cease. Cells formed brownish layers on the inner glass surfaces of the culture flasks. Phase-contrast micrographs showed highly refractive cells that were obviously surrounded by iron oxides, including the stalks (Fig. 1b).

Also, the type strain of $\mathrm{Rm}$. vannielii oxidized ferrous iron in the light. A detailed comparison of strain BS-1 with the $R m$. vannielii type strain revealed that strain BS-1 behaves similarly to $R m$. vannielii in utilization of substrates. Differences were found only in the utilization of benzoate, tartrate, aspartate and glutamate, which were utilized exclusively by strain BS-1, and sulfide, methanol and ethylene glycol, which were used only by $R m$. vannielii (Table 1 ). The pigmentation of both strains was examined by recording in vivo absorption spectra after photoheterotrophic growth with succinate. Absorption spectra of these strains (Fig. 2) were identical, with maxima at $375,592,803$ and $868 \mathrm{~nm}$, typical of bacteriochlorophyll $a$ (Pfennig \& Trüper, 1991), and carotenoid absorption maxima at 460,487 and $523 \mathrm{~nm}$, indicating the presence of lycopene and rhodopene (Pfennig \& Trüper, 1991). Both cultures appeared orange-brown after growth with succinate. Strain BS-1 was also able to grow aerobically in the dark with succinate as carbon and energy source.

\section{Growth of strain BS-1 with ferrous iron}

Addition of $8 \mathrm{mM} \mathrm{FeSO}_{4}$ to the bicarbonate-buffered medium caused the formation of a white precipitate of $\mathrm{FeCO}_{3}$. Growth in mineral medium with ferrous iron as

Table 1. Utilization of substrates by strain BS-1 and $R m$. vannielii type strain

\begin{tabular}{|c|c|c|}
\hline $\begin{array}{l}\text { Substrates tested for support } \\
\text { of phototrophic growth }\end{array}$ & Strain BS-1 & $\begin{array}{l}\text { Rm. vannielii } \\
\text { type strain* }\end{array}$ \\
\hline $\begin{array}{l}\mathrm{H}_{2} / \mathrm{CO}_{2} \text {, acetate, propionate, butyrate, } \\
\text { valerate, caproate, caprylate, lactate, } \\
\text { pyruvate, ethanol, malate, malonate, } \\
\text { fumarate }\end{array}$ & + & + \\
\hline Glucose, fructose, citrate, glycolate & - & - \\
\hline Benzoate, tartrate, aspartate, glutamate & + & - \\
\hline $\mathrm{HS}^{-}$, methanol, ethylene glycol & - & + \\
\hline $\begin{array}{l}\text { Glyoxylate, mercaptoethanol, cyclohexane } \\
\text { carboxylate, cysteine }\end{array}$ & - & ND \\
\hline
\end{tabular}

*Data from Whittenbury \& Dow (1977). ND, Not determined. 


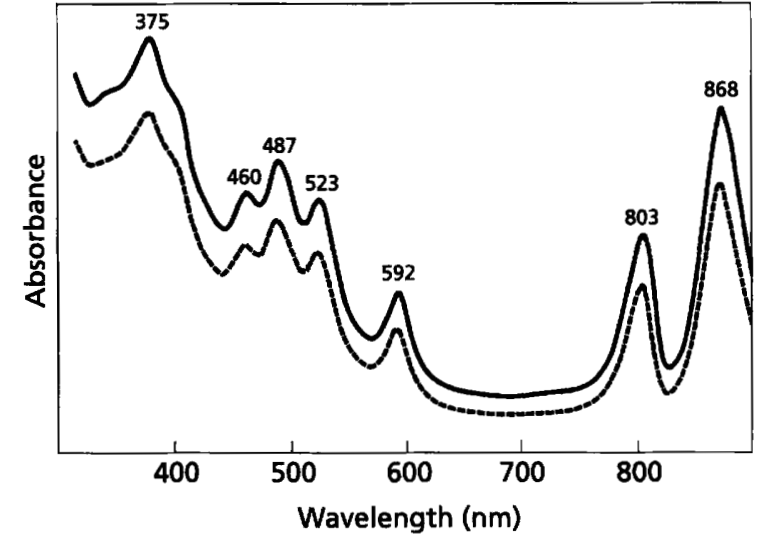

Fig. 2. Absorption spectra of living cells of strain BS-1 $(-)$ and $R m$. vannielii type strain (--). Both strains were grown with $6 \mathrm{mM}$ succinate; the protein content was $0.25 \mathrm{mg} \mathrm{ml}^{-1}$.

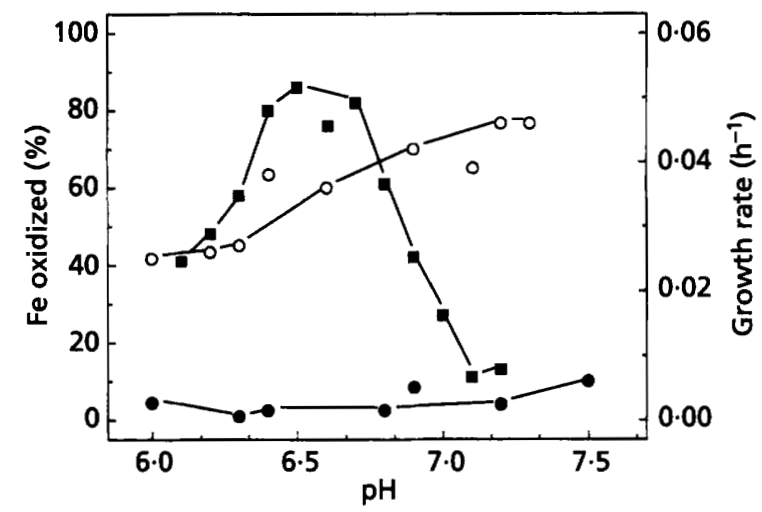

Fig. 3. Influence of medium $\mathrm{pH}$ on growth and Fe(II) oxidation by strain BS-1. End points of growth were determined after $32 \mathrm{~d}$ incubation. $\square, \mathrm{Fe}(\mathrm{II})$ oxidation by cells grown with $8 \mathrm{mM}$ $\mathrm{FeSO}_{4}$ plus $1 \mathrm{mM}$ acetate; 9 , sterile controls with $8 \mathrm{mM} \mathrm{FeSO}_{4}$; 0 , heterotrophic growth with acetate $(2.5 \mathrm{mM})$.

sole electron source was slow; after 8 weeks, approximately $50 \%$ of the added ferrous ions was oxidized. Addition of an organic cosubstrate enhanced growth substantially; these cosubstrates were provided at concentrations releasing equivalent amounts of electrons for photosynthetic electron transport $(1 \mathrm{mM}$ acetate, $0.6 \mathrm{mM}$ succinate, $0.7 \mathrm{mM}$ malate, $0.8 \mathrm{mM}$ pyruvate or $0.4 \mathrm{mM}$ butyrate). No difference in iron oxidation activity was found if the $\mathrm{HCl}$-based solution SL10 or the EDTA-based solutions SL9 and SL12 were used as trace element solutions.

As the solubility of iron salts depends strictly on the prevailing $\mathrm{pH}$, the $\mathrm{pH}$-dependence of growth and iron oxidation was studied. Whereas the growth rate with acetate as substrate increased continuously with increasing $\mathrm{pH}$, iron oxidation activity exhibited an optimum at approximately $\mathrm{pH} 6 \cdot 4-6.7$, and no iron oxidation was observed at $\mathrm{pH}>7 \cdot 1$ (Fig. 3 ). The in vivo absorption spectra of intact cells grown with either

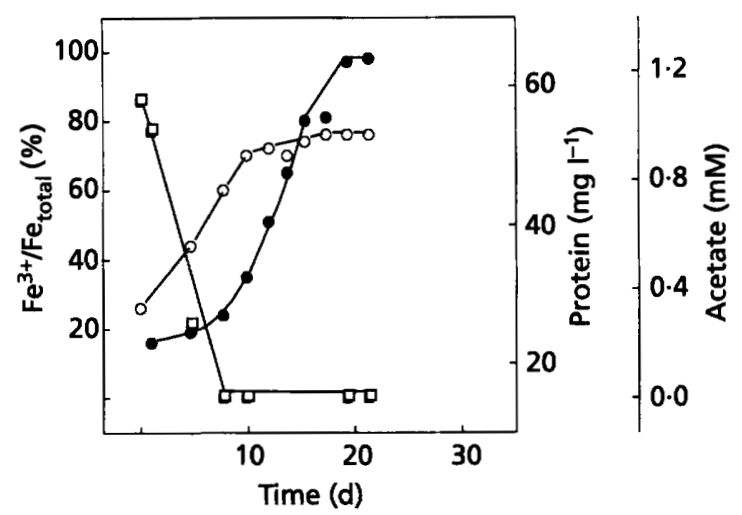

Fig. 4. Growth and ferrous iron oxidation by strain BS-1 with $8 \mathrm{mM} \mathrm{FeSO}{ }_{4}$ plus $1 \mathrm{mM}$ acetate $(\square)$ and $15 \mathrm{mM} \mathrm{NTA}$. Percentage $\mathrm{Fe}^{3+} / \mathrm{Fe}_{\text {total }} ; O$, protein. Control cultures without ferrous iron gave no indication of NTA utilization. Uninoculated control cultures did not oxidize ferrous iron.

acetate alone or $1 \mathrm{mM}$ acetate plus $8 \mathrm{mM} \mathrm{FeSO}_{4}$ were identical (results not shown).

Strain BS-1 did not oxidize $\mathrm{Mn}(\mathrm{II})$ salts provided as $4 \mathrm{mM} \mathrm{MnSO}$, which precipitated in the medium as reddish-white $\mathrm{MnCO}_{3}$. Formation of dark-stained oxidation products was not observed, neither in the presence nor in the absence of acetate as organic cosubstrate.

Strain BS-1 did not reduce Fe(III) salts in the dark with acetate or succinate as electron donor. Neither exogenously provided amorphous $\mathrm{FeOOH}$ nor $\mathrm{Fe}$ (III) oxohydroxides produced by the cells themselves were reduced under such conditions. The same was true for the $R m$. vannielii type strain. In both strains, $\mathrm{MnO}_{2}$ was not reduced in the dark with acetate as electron donor.

\section{Effect of complexing agents on iron oxidation activity}

Several complexing agents were checked for possible support of iron oxidation activity by strain BS-1. EDTA $(0.2 \mathrm{mM}, 0.5 \mathrm{mM})$ and NTA $(1 \mathrm{mM})$ stimulated iron oxidation rates by $>50 \%$ as compared to a chelatorfree control. NTA or EDTA alone did not serve as electron source. Citrate had no stimulating effect at $1-10 \mathrm{mM}$ concentration. In the presence of $15 \mathrm{mM}$ $\mathrm{NTA}$, the $\mathrm{FeSO}_{4}$-containing medium stayed entirely clear and optical analysis of time courses of growth and iron oxidation became possible. However, NTA at $15 \mathrm{mM}$ concentration decreased the acetate- or irondependent growth rates by approximately $30 \%$. Moreover, iron oxidation in these cultures was not associated with stoichiometric cell mass increase: after acetate consumption, the cell mass did not increase any further, but iron was oxidized slowly, without concomitant cell mass formation (Fig. 4).

Ultrathin sections of cells grown with ferrous iron plus acetate in the presence or absence of NTA revealed clear 

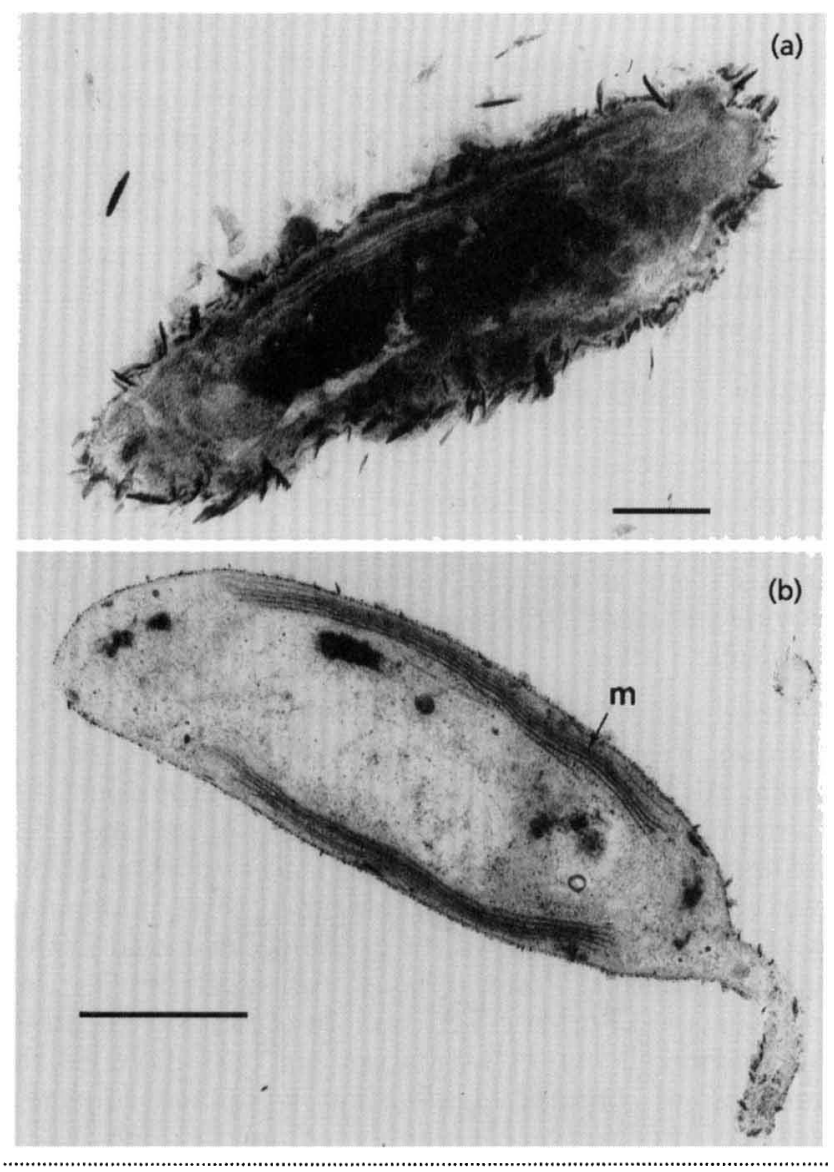

Fig. 5. Transmission electron micrographs of ultrathin sections of strain BS-1. Cells were grown with either $8 \mathrm{mM} \mathrm{FeSO}_{4}$ plus $1 \mathrm{mM}$ acetate (a) or $8 \mathrm{mM} \mathrm{FeSO}$ plus $1 \mathrm{mM}$ acetate and $15 \mathrm{mM}$ NTA (b). m, Intracytoplasmic membranes. Courtesy of Professor Dr F. Mayer, University of Gottingen. Bars, $100 \mathrm{~nm}$ (a) and $500 \mathrm{~nm}(\mathrm{~b})$.

differences in cell ultrastructure (Fig. $5 \mathrm{a}, \mathrm{b}$ ). Whereas cells grown with $\mathrm{FeCO}_{3}$ were covered with numerous crystalline, electron-dense precipitates inside the cells and on the cell surface, cells grown in the presence of NTA did not show such precipitates but exhibited the lamellar intracytoplasmic membrane structures typical of the genus Rhodomicrobium.

Cell-free extracts of cells grown with ferrous iron plus NTA, $\mathrm{H}_{2}$ plus NTA, or with $\mathrm{H}_{2}$ plus ferrous iron plus NTA were subjected to SDS-PAGE. The band pattern of all three extracts did not differ qualitatively, but at least two bands in the molecular mass range $12-14 \mathrm{kDa}$ were significantly thicker in extracts of iron-grown cells than in extracts of cells grown in the absence of ferrous iron (Fig. 6a). These could be stained by haem staining, indicating that they represent cytochromes (Fig. 6b).

\section{Iron oxidation by other strains of purple non-sulfur bacteria}

Several pure cultures of purple non-sulfur bacteria were checked for their ability to oxidize Fe(II) salts provided either as $\mathrm{FeCO}_{3}$ or FeS. As well as strain BS-1 and $R m$. (a)

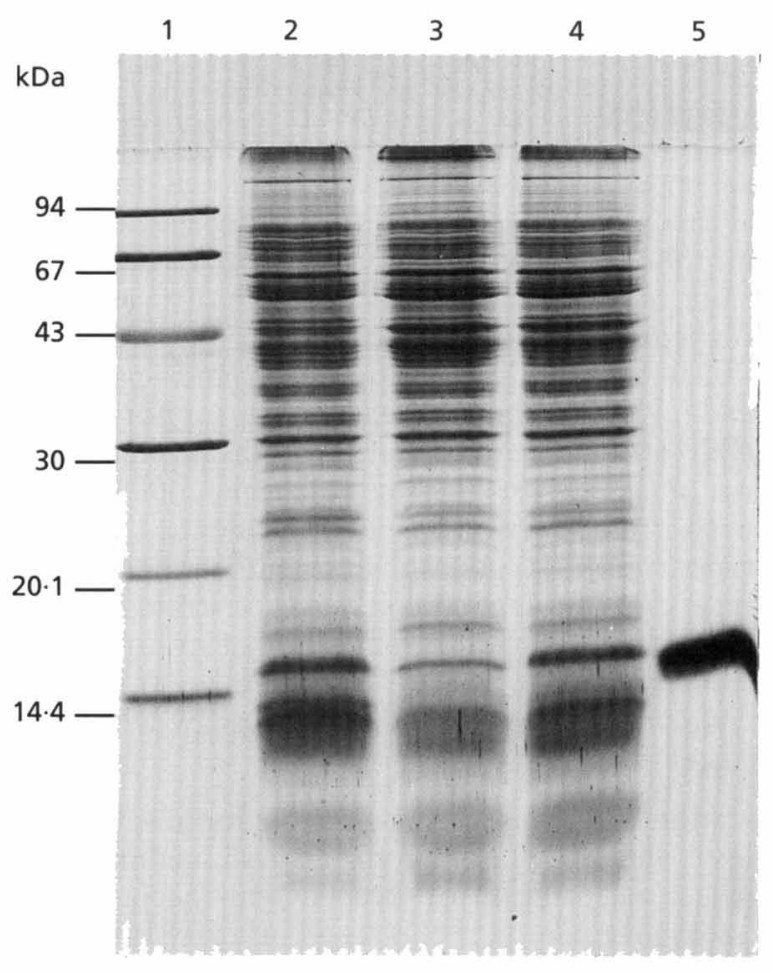

(b)

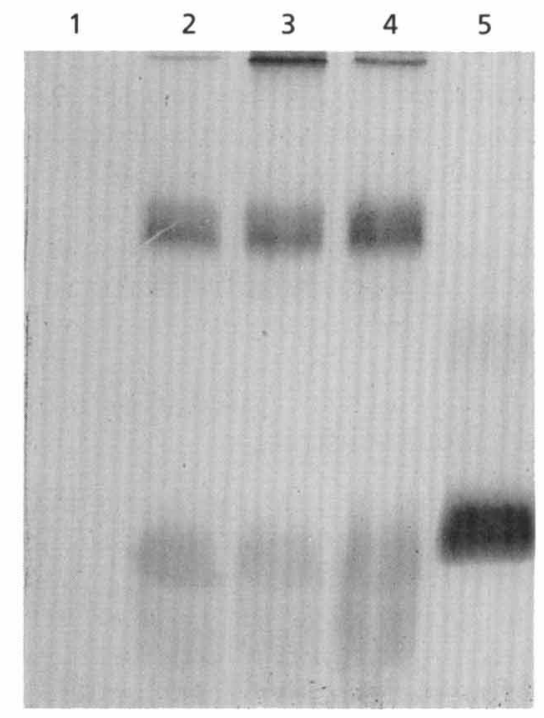

Fig. 6. SDS-PAGE separation of total proteins in cell-free extracts of strain BS-1 (30 $\mu \mathrm{g}$ protein per lane). Numbers on the left side refer to molecular masses of standard proteins. (a) Gel stained with Coomassie blue for proteins; (b) gel stained for haem by haem peroxidase. Lanes: 1, standard marker proteins; 2, cells grown with $\mathrm{FeSO}_{4}$ plus NTA; 3 , cells grown with $\mathrm{H}_{2}$ plus NTA; 4, cells grown with $\mathrm{H}_{2}$ plus $\mathrm{FeSO}_{4}$ plus NTA; 5, cytochrome $c$ from horse heart.

vannielii, $\mathrm{Fe}(\mathrm{II})$ was also oxidized by Rhodobacter capsulatus, Rhodopseudomonas palustris and Rhodospirillum rubrum, either alone or in the presence of $\mathrm{H}_{2}$ or yeast extract as cosubstrates. With Rhodobacter 
sphaeroides and Rhodopseudomonas acidophila, no iron oxidation activity was observed.

\section{DISCUSSION}

Unlike most bacteria, the newly isolated strain BS-1 could easily be affiliated with an existing species, mainly on morphological grounds. The formation of motile swarmer cells, stalked cells attached to surfaces, as well as polyhedral exospores indicated that this strain had to be affiliated with the existing genus and species $R m$. vannielii. This assumption was further supported by the lamellar arrangement of intracytoplasmic membranes typical of this species (Imhoff \& Trüper, 1991), and by the absorption spectrum, which was identical to that of the type strain. Also, the substrate utilization spectra of the type strain of $R m$. vannielii and of strain BS-2 were sufficiently similar to allow affiliation of strain BS-1 with the species $R m$. vannielii. Finally, the type strain of $R m$. vannielii was also found to be able to grow with ferrous iron as electron donor.

Utilization of ferrous iron as electron donor is limited by the low solubility of $\mathrm{Fe}^{2+}$ in the growth medium. At $\mathrm{pH}$ $7 \cdot 2$, the concentration of free $\mathrm{Fe}^{2+}$ in the presence of excess bicarbonate is in the range of a few micromolar (Ehrenreich \& Widdel, 1994). At higher $\mathrm{pH}$, the solubility decreases drastically. This relationship may be the reason for the observed $\mathrm{pH}$ dependence of ferrous iron oxidation by strain BS-1 (Fig. 3): the pH optimum of ferrous-iron-dependent photosynthesis was substantially lower than that of succinate-dependent photosynthesis, and there was hardly any ferrous iron oxidation at $\mathrm{pH}>7 \cdot 0$. Organic cosubstrates (acetate, butyrate, malate, succinate, pyruvate) increased the rate of iron oxidation considerably, perhaps by complexation of $\mathrm{Fe}^{2+}$, but probably more by enhanced growth with additional electron sources and increased cell surface areas, which increased in turn the contact area with the ferrous substrate.

The products formed by iron oxidation $[\mathrm{FeOOH}$ and $\left.\mathrm{Fe}(\mathrm{OH})_{3}\right]$ have even lower solubility products $\left[K_{\mathrm{L}}=\right.$ $6 \times 10^{-36}$ for $\mathrm{Fe}(\mathrm{OH})_{3}$; Mortimer, 1987] than the substrate $\mathrm{FeCO}_{3}\left(K_{\mathrm{L}}=2 \cdot 1 \times 10^{-11}\right)$. The ferric oxohydroxides precipitated on the cell surfaces, forming crystals of various sizes. It is evident that ferrous iron is oxidized at the cell surface, and the insoluble oxohydroxides precipitated exactly there, forming thick, refractile crusts which impeded further oxidation after prolonged cultivation.

Other ferrous-iron-oxidizing phototrophs (strains SW2 and L7; Ehrenreich \& Widdel, 1994) form ferric iron oxohydroxides separate from the cells which prevent enclosure of the cells with insoluble rust covers. It is evident that there are individual differences between the various strains of ferrous-iron-oxidizing phototrophs with respect to the site of ferric oxide deposition, e.g. due to excretion of short-chain carboxylic acids which may act as chelating agents for $\mathrm{Fe}^{2+}$. The solubility of ferrous iron ions in culture supernatants from different strains of ferrous-iron-oxidizing phototrophs differed by about two orders of magnitude, indicating that complexing agents were excreted $(R$. Warthmann \& B. Schink, unpublished results). Culture supernatants of strain BS-1 contained very little ferrous iron, which may be the reason for the observed accrustation of ferric iron oxohydroxides on the cell surfaces, and which may also explain the comparatively slow growth of this strain with ferrous iron.

Aerobic mixotrophic iron-oxidizing bacteria such as Sphaerotilus natans and Leptothrix discophora precipitate ferric oxohydroxides in sheets of acidic exopolymers on the cell surface (van Veen et al., 1978; Ghiorse, 1984). Obviously, these bacteria also oxidize ferrous irons at the cell surface but the thick sheets provide sufficient protection to the cells to allow further metabolic activity.

We tried to avoid the ferric hydroxide precipitations by addition of complexing agents, especially NTA, to the media. Although ferrous and ferric iron ions could be maintained in solution with $15 \mathrm{mM}$ NTA, and the cells still exhibited active growth with acetate as electron source, they were obviously damaged by this complexing agent, perhaps by removal of divalent cations from the outer membrane. Thus ferrous iron oxidation in the presence of $15 \mathrm{mM}$ NTA was not coupled to stoichiometric cell matter formation but may have led to synthesis of organic acids that were subsequently excreted into the surrounding medium through leaky membranes.

The acidophilic aerobic ferrous-iron-oxidizing bacteria Thiobacillus ferrooxidans and Leptospirillum ferrooxidans produce specific proteins for oxidation of ferrous iron which are located in the periplasm (Blake $e t$ al., 1993). By analogy to these aerobic ferrous iron oxidizers, we assume that iron oxidation in the phototrophic bacteria is localized on the outside of the cytoplasmic membrane as well. Periplasmic electron carriers similar to the rusticyanins of the aerobic acidophilic iron oxidizers may transfer these electrons to cytochrome $c_{2}$ and with this to the photosystems (Ehrenreich \& Widdel, 1994). If such carriers were present only in insufficient amounts, part of the iron oxidation process would also occur in the periplasm, with the observed detrimental effect for the cells.

The protein band pattern of cell-free extracts of cells grown with ferrous iron differed only quantitatively from those grown with hydrogen in the absence of ferrous iron. Obviously, there was no difference in the photosynthetic apparatus used in the presence or absence of ferrous iron, and there was no indication of a specific cytochrome that was specifically involved in iron oxidation. However, at least two protein bands that probably corresponded to cytochromes were substantially increased in iron-grown cells, indicating that such a carrier is induced to higher activity in ferrous iron oxidation. The fact that only few phototrophic bacteria among those tested turned out to be able to use ferrous iron as electron donor indicates that this metabolic 
capacity depends on a specific arrangement of carrier systems that is not present in every phototrophic bacterium. The difference may be due to a specific arrangement of carrier systems, perhaps to a specific exposure of such carriers to the periplasmic space which allows access of ferrous iron ions only with certain strains, or to an enhanced synthesis of a periplasmic (?) cytochrome that could mediate electron flow from outside across the periplasmic space.

The physiological advantage of ferrous iron oxidation by strain BS-1 is still enigmatic. Since ferric iron crusts deposited on the cell surface were not reduced or redissolved upon exposure to organic substrates in the dark, this process appears to be an irreversible reaction that impairs the cell physiology on a long-term basis. Also, the phototrophic isolates L7 and SW2 did not reduce ferric iron precipitates in the dark (Ehrenreich $\&$ Widdel, 1994). On the other hand, iron oxidation must provide some advantage to strain BS-1 because it could be enriched with iron as sole electron donor from sediments in the presence of trace amounts of organic acids in the inoculum material during the first enrichment steps. We assume that in nature, strain BS-1 finds ways to redissolve thin crusts of ferric iron hydroxides after oxidative precipitation, but we were unable to mimic such culture conditions in the laboratory.

We conclude that ferrous iron oxidation by strain BS-1 may be only a side activity of minor physiological importance. Ferrous iron oxidation may be of advantage to the cells in nature as long as sufficient concomitant cell surface increase is secured by organic cosubstrates to avoid complete coverage of the cell surface by rusty layers.

\section{ACKNOWLEDGEMENTS}

The authors are indebted to Professor Dr Frank Mayer, Göttingen, for taking the electron micrographs. Advice by Professor Dr Norbert Pfennig, Konstanz, on aspects of the physiology and cultivation of phototrophic bacteria is greatly appreciated. This study was supported by the Deutsche Forschungsgemeinschaft, Bonn-Bad Godesberg, in its special research programme SFB 248 'Cycling of Matter in Lake Constance'.

\section{REFERENCES}

Blake, R. C., II, Shute, E. A., Greenwood, M. M., Spencer, G. H. \& Ingledew, W. J. (1993). Enzymes of aerobic respiration on iron. FEMS Microbiol Rev 11, 9-18.

Cline, J. D. (1969). Spectrophotometric determination of hydrogen sulfide in natural waters. Limnol Oceanogr 14, 454 458.

Ehrenreich, A. \& Widdel, F. (1994). Anaerobic oxidation of ferrous iron by purple bacteria, a new type of phototrophic metabolism. Appl Environ Microbiol 60, 4517-4526.

Ehrlich, H. L. (1990). Geomicrobiology, pp. 283-346. New York: Marcel Dekker.
Ghiorse, W. C. (1984). Biology of iron- and manganese-depositing bacteria. Annu Rev Microbiol 38, 515-550.

Heising, S., Dilling, W., Schnell, S. \& Schink, B. (1996). Complete assimilation of cysteine by a newly isolated non-sulfur purple bacterium resembling Rhodovulum sulfidophilum (Rhodobacter sulfidophilus). Arch Microbiol 165, 397-401.

Imhoff, J. F. \& Truper, H. G. (1991). The genus Rhodospirillum and related genera. In The Prokaryotes, 2nd edn, pp. 2141-2155. Edited by A. Balows, H. G. Trüper, W. Harder \& K. H. Schleifer. Berlin: Springer.

Laemmli, U. K. (1970). Cleavage of structural proteins during the assembly of the head of bacteriophage T4. Nature 227, 680-685.

Lovley, D. R. (1993). Dissimilatory metal reduction. Annu Rev Microbiol 47, 263-290.

Lovley, D. R. \& Phillips, E. J. P. (1986). Organic matter mineralization with reduction of ferric iron in anaerobic sediments. Appl Environ Microbiol 51, 683-689.

Lovley, D. R. \& Phillips, E. J. P. (1988). Novel mode of microbial energy metabolism: organic carbon oxidation coupled to dissimilatory reduction of iron or manganese. Appl Environ Microbiol 54, 1472-1480.

Mayer, F., Lurz, R. \& Schoberth, S. (1977). Electron microscopic investigation of the hydrogen-oxidizing acetate-forming anaerobic bacterium Acetobacterium woodii. Arch Microbiol 115, 207-213.

Mortimer, C. E. (1987). Chemie. Stuttgart: Georg Thieme.

Neilands, J. B. (1974). Iron and its role in microbial physiology. In Microbial Iron Metabolism, pp. 3-34. Edited by J. B. Neilands. New York: Academic Press.

Pfennig, N. (1978), Rhodocyclus purpureus, gen. nov. and sp. nov., a ring-shaped vitamin $B_{12}$-requiring member of the family Rhodospirillaceae. Int J Syst Bacteriol 28, 283-288.

Pfennig, N. \& Truper, H. G. (1991). The family Chromatiaceae. In The Prokaryotes, 2 nd edn, pp. 3200-3221. Edited by A. Balows, H. G. Trüper, M. Dworkin \& K. H. Schleifer. Berlin: Springer.

Platen, H. \& Schink, B. (1987). Methanogenic degradation of acetone by an enrichment culture. Arch Microbiol 149, 136-141.

Spurr, A. R. (1969). A low-viscosity epoxy resin embedding medium for electron microscopy. J Ultrastruct Res 26, 31-43.

Stookey, L. L. (1970). Ferrozine-a new spectrophotometric reagent for iron. Anal Chem 42, 779-781.

Stumm, W. \& Morgan, J. J. (1981). Aquatic Chemistry. New York: Wiley.

Thomas, P. E., Ryan, D. \& Levin, W. (1976). An improved staining procedure for the detection of the peroxidase activity of cytochrome P-450 on sodium dodecyl sulfate polyacrylamide gels. Anal Biochem 75, 168-176.

van Veen, W. L., Mulder, E. G. \& Deinema, M. H. (1978). The Sphaerotilus-Leptothrix group of bacteria. Microbiol Rev 42, 329-356.

Whittenbury, R. \& Dow, C. S. (1977). Morphogenesis and differentiation in Rbodomicrobium vannielii and other budding and prosthecate bacteria. Bacteriol Rev 41, 754-808.

Widdel, F., Schnell, S., Heising, S., Ehrenreich, A., Assmus, B. \& Schink, B. (1993). Ferrous iron oxidation by anoxigenic phototrophic bacteria. Nature 362, 834-836.

Received 27 February 1998; revised 20 April 1998; accepted 22 April 1998. 